AJIE - Asian Journal of Innovation and Entrepreneurship

(e-ISSN: 2477- 0574; p-ISSN: 2477-3824)

Vol. 01, No. 01, January 2016

\title{
PENGEMBANGAN USAHA TEPUNG IKAN DI DESA NELAYAN PUGER WETAN
}

\author{
Halimatus Sa'diyah', Alfian Futuhul Hadi' ${ }^{2}$, Nasrul Ilminnafik ${ }^{3}$ \\ ${ }^{1}$ Agronomi Departemen, Universitas Jember, Indonesia \\ ${ }^{2}$ Jurusan Matematika, Universitas Jember, Indonesia \\ ${ }^{3}$ Jurusan Teknik Mesin, Universitas Jember, Indonesia \\ E-mail:sadiyah79@gmail.com
}

\begin{abstract}
Puger Wetan is the largest fisheries center in Jember. One of the fish type produced is SardinellaLemuru. Due to its small size and prickly nature, it is rarely consumed directly. It is commonly sold as raw material for canned sardines. Canned sardines manufacture needs fresh Lemuru, because it will cause itching on the tongue if not fresh. Whereas, fishermen mostly piled the fish in the boat hatch then gave ice cubes, so that the majority of it will no longer be fresh when arrived in the mainland because its perishable nature due to its thin skin.As the result, most of fishermen's catch is not feasible for canned sardines and become leftovers. During this time, it will be sold at a low price. Fish leftovers that are not absorbed by the market aredumped into the river, becomingleftovers. The waste pollutes the environment and harms the health and hygiene. There will be more wastes during the fishing season, as more and more lemuru leftovers are dumped. This activity aims to resolve the problem by transforming the leftovers into fish meal, using appropriate tech machines. The activities are carried out in several stages. The first stage is the counseling about the negative impact of fisheries waste and the possibility of utilizing it into fish meal, also about the business opportunity that is still potential because domestic demand is still not yet met. The explanation of the importance of business management was also given.The third stage is the practice of making fish meal with the help of tools that have been previously converted technology. The fourth stage is the evaluation of activities for the benefit of partnering groups. Lemuru leftover utilization into fish meal is one of the important components in animal feed which can increase the fishermen income, while reducing environmental pollution.
\end{abstract}

Keywords: fish meal, disc mill

\section{ABSTRAK}

Puger Wetan merupakan pusat perikanan terbesar di Jember. Salah satu jenis ikan yang dihasilkan adalah SardinellaLemuru. Karena ukurannya yang kecil dan sifat berduri, jarang dikonsumsi langsung. Hal ini umumnya dijual sebagai bahan baku sarden kalengan. Sedangkan nelayan sebagian besar menumpuk ikan di palka perahu kemudian memberi es batu, sehingga mayoritas itu tidak lagi segar ketika tiba di daratan karena kulitnya yang tipis. Sebagian besar hasil tangkapan nelayan tidak layak untuk sarden kalengan dan menjadi sisa. Selama waktu itu akan dijual dengan harga murah. sisa ikan yang tidak terserap pasar dibuang ke sungai menjadi limbah yang mencemari lingkungan dan merugikan kesehatan dan kebersihan. Akan ada lebih banyak limbah selama musim memancing, karena semakin banyak sisa lemuru dibuang. Kegiatan ini bertujuan untuk menyelesaikan masalah dengan mengubah sisa-sisa makanan menjadi tepung ikan, menggunakan mesin berteknologi tepat. Kegiatan yang dilakukan dalam beberapa tahap. Tahap pertama adalah penyuluhan tentang dampak negatif dari limbah perikanan dan kemungkinan memanfaatkan itu menjadi tepung ikan, juga tentang peluang bisnis yang masih potensial karena 
permintaan dalam negeri masih belum terpenuhi. Penjelasan tentang pentingnya manajemen bisnis juga given.The Tahap ketiga adalah praktek membuat makan ikan dengan bantuan alat-alat yang sebelumnya telah dikonversi teknologi. Tahap keempat adalah evaluasi kegiatan untuk kepentingan kelompok bermitra. Lemuru sisa pemanfaatan menjadi tepung ikan adalah salah satu komponen penting dalam pakan ternak yang dapat meningkatkan pendapatan nelayan, sekaligus mengurangi pencemaran lingkungan.

Kata kunci: makan ikan, pabrik disc

\section{PENDAHULUAN}

Kecamatan Puger berada di Kabupaten Jember, tepatnya $47 \mathrm{~km}$ di sebelah barat, tepat di tepi pantai selatan. Sebagai desa nelayan, banyak masyarakat Puger yang bekerja di bidang perikanan, baik sebagai nelayan, pedagang ikan, maupun usaha pengolahan ikan seperti ikan asin dan terasi. Jenis ikan yang banyak adalah tongkol, tuna, lemuru, dan tengiri. Khusus untuk ikan lemuru, dapat ditangkap hampir sepanjang tahun, meskipun jumlahnya berfluktuasi, sehingga nelayan bisa tiap hari mencari ikan asalkan cuaca memungkinkan. Ikan Lemuru hasil tangkapan nelayan dibeli oleh pengepul untuk dijual kembali ke perusahaan sarden kaleng. Ikan lemuru jarang dikonsumsi dalam kondisi segar karena memiliki banyak duri dan ukurannya relatif kecil, sehingga lebih sulit dilakukan pengolahan. Ikan lemuru yang dibeli pengepul adalah yang masih segar karena mempengaruhi kualitas sarden. Ikan yang tidak dibeli pengepul menjadi ikan sisa dengan harga jual murah karena di kalangan penjual ikan segar, lemuru tergolong ikan yang tidak disukai karena gampang busuk dan mudah rusak.

Berdasarkan pengamatan di lokasi, nelayan biasa menumpuk begitu saja lemuru tangkapannya di atas palka dengan es balok yang minim. Karena penanganan yang buruk ini, mutunya cepat sekali merosot. Saat sampai di darat, sebagian sudah mulai busuk, sehingga ikan ini dibuang begitu saja, ditumpuk di pinggir sungai atau dibuang ke sungai, menjadi limbah, dan mengakibatkan air sungai menjadi berminyak. Banyaknya ikan yang busuk dan tidak laku dijual membuat para nelayan sering mengalami kerugian karena hasil penjualan tangkapannya tidak sebanding dengan tenaga dan biaya yang dikeluarkan untuk melaut.

Pada musim tangkap lemuru, sekitar bulan oktober-desember, nelayan biasa memperoleh lemuru dalam jumlah besar, sehingga jumlah lemuru yang tidak terserap pasar dan menjadi limbah semakin banyak. Hal ini tentu saja mengganggu keindahan dan kebersihan lingkungan, menebarkan aroma tidak sedap, dihinggapi lalat yang dapat menimbulkan penyakit, menjadi tempat pertumbuhan bakteri dan virus patogen, serta berbagai dampak negatif lainnya.

Untuk mengurangi dampak negatif yang ditimbulkan, serta meningkatkan penghasilan nelayan, ikan sisa tersebut harus dimanfaatkan agar memiliki nilai tambah. Berdasarkan pengamatan, nilai tambah tertinggi bisa didapatkan dengan mengolah limbah ikan lemuru menjadi tepung ikan (fish meal). Peluang usaha tepung ini sangat prospektif karena saat ini industri pembuat tepung ikan masih sedikit, sehingga masih banyak ikan yang terbuang. Hal ini tentu mengakibatkan pemborosan sumber daya.

Komoditas tepung ikan memiliki peluang pemasaran yang prospektif, baik untuk pasaran dalam maupun luar negeri. Kebutuhan tepung ikan sebagai bahan baku pakan Indonesia cukup besar, namun Karen produksi tepung ikan masih minim, maka 90\% harus diimpor. Pada tahun 2011, impor tepung ikan Indonesia sebesar 167,224,729 kg atau senilai USD 44,384,799 dengan rata-rata 
kenaikan impor per tahun sebesar 39\% (KKP, 2012). Sedangkan tahun 2014, menurut Dirjen Pengolahan dan Pemasaran Hasil Perikanan (KKP), kebutuhan tepung ikan tahun 2014 sebesar 90.000 ton, dan impor tepung ikan sebesar 80.000 ton mencapai US\$ 480 juta atau Rp 5,7 triliun (Nurhayat, 2015).

Berdasarkan analisis situasi tersebut, dapat diuraikan beberapa masalah yang dihadapi oleh kelompok nelayan tersebut, yaitu:

1. Pemanfaatan ikan masih terbatas sebagai produk untuk dipasarkan langsung (ikan segar), terutama untuk bahan baku sarden kaleng.

2. Belum adanya pengetahuan cara pemanfaatan ikan sisa sehingga hanya dibuang dan menjadi sampah yang mengganggu.

3. Tidak adanya alat-alat yang memadai untuk pengolahan limbah ikan menjadi olahan yang bermanfaat, khususnya untuk menjadi tepung ikan.

4. Perlunya pengembangan usaha untuk meningkatkan pendapatan mereka selain melaut mencari ikan. Apalagi pada saat kondisi laut tidak memungkinkan, nelayan tidak bisa melaut dan tidak memperoleh pendapatan.

5. Belum memahami tentang managemen usaha dan pembukuan.

Berdasarkan permasalahanpermasalahan tersebut, maka masalah utama yang harus diselesaikan adalah pemanfaatan limbah padat dari ikan, yaitu berupa ikan sisa yang tidak tertampung di pasar maupun di industri pengolahan. Dengan termanfaatkannya limbah ikan tersebut, selain berdampak positif dalam mengurangi pencemaran lingkungan sekitar, juga menciptakan adanya diversifikasi usaha kelompok nelayan tersebut, meningkatkan pendapatan, dan pada akhirnya dapat meningkatkan kesejahteraan mereka.

\section{TINJAUAN PUSTAKA}

\section{Tepung Ikan}

Tepung Ikan adalah ikan atau bagianbagian ikan yang minyaknya diambil atau tidak, dikeringkan kemudian digiling. Kegunaan utama tepung ikan adalah sebagai bahan campuran pada makanan ternak. Secara umum, setiap jenis ikan dapat diolah menjadi tepung ikan. Pemilihan jenis ikan yang akan dijadikan bahan pembuat tepung harus memperhatikan karakteristik ikan, nilai ekonomis dan ketersediaan. Salah satu karakter ikan yang penting adalah kadar lemaknya karena berpengaruh pada kualitas tepung. Kadar lemak ikan jika terlalu tinggi akan berpengaruh buruk terhadap kualitas tepung ikan. Ikan pelagis, yaitu ikan-ikan yang biasa hidup dilapisan air bagian atas, memiliki kadar lemak yang relatif tinggi. Sedangkan ikan jenis demersal, yang biasa hidup di dasar perairan, kadar lemaknya relatif rendah. Ikan dikategorikan memiliki kadar lemak rendah jika kadar lemaknya 3$5 \%$, dan digolongkan tinggi jika lebih dari 10\% (Murtijdo, 2003).

Lemuru merupakan salah satu jenisikan pellagis yang banyak dibuat tepung ikan. Untuk menghilangkan kandungan lemaknya, terlebih dahulu dilakukan perebusan sebelum dijemur. Lemuru adalah kelompok sardinella, dimana musim tangkap puncaknya pada sekitar bulan November. Panjang badan umumnya antara $15-18 \mathrm{~cm}$ (Merta, 1992), berkilau pada bagian perut dan kebiruan pada bagian punggung (Amri, 2007). Berdasarkan hasil penelitian lemuru mengandung protein tinggi sehingga dapat dimanfaatkan sebagai nutrisi pada pakan ternak. Kandungan nutrisi dalam tepung ikan adalah protein 60-75\%, lemak 6-14\%, kadar air 4-12\% dan kadar abu 6-18\% (Akhiarif, 2011). Tepung ikan tersebut sebagai bahan campuran bergizi dalam pakan ternak. Persentase tepung ikan dalam pakan ternak untuk ayam maupun itik petelor 5$10 \%$, itik potong $12 \%$, puyuh $10 \%$ (Alfiyah, 
2012). Khusus tepung ikan dari lemuru dapat meningkatkan omega-3 pada telur ayam (Redjeki \& Trinovani, 2012).

Dari 20 ton ikan basah dapat diolah menjadi 9 ton tepung ikan (Sukirno \& Sriharti, 2000). Hasil sampingan dari pembuatan tepung ikan adalah minyak ikan. Menurut Prabowo (2004), minyak ikan lemuru merupakan limbah hasil pengolahan tepung ikan yang banyak mengandung Eicosapentaenoic Acid (EPA) dan Docosahexanoic Acid (DHA) yang termasuk dalam asam lemak omega-3 (linolenat). Hasil penelitian pada ikan nila gift (Oreochormis $s p)$ telah mendapatkan bahwa pelet stimulant pakan ikan (SPI) dengan nilai protein $30 \%$ dapat meningkatkan bobot badan ikan nila gift (Oreochormis sp) dari 100 g selama 4 bulan menjadi $575 \mathrm{~g}$.

Tepung ikan mengandung protein hewani yang tinggi, tersusun dari asam-asam amino esensial yang komplek, diantaranya Lisin dan Methionin, juga mengandung mineral Calsium dan Phospor, serta vitamin B kompleks khususnya vitamin B12. Bila ditinjau dari sisi kualitasnya sampai saat ini tepung ikan masih sulit untuk mencari substitusinya. Indonesia memiliki potensi yang besar bagi pengembangan produk tepung ikan. Industri skala kecil pengolahan dan pembuatan tepung ikan di Indonesia, akan sangat tepat diterapkan, mengingat kesediaan bahan baku ikan rucah maupun sisa olahan cukup besar. Besarnya impor tepung ikan rata-rata pertahun bagi pabrik makanan ternak dan ikan mengalami kenaikan 11,20 \% . Hal ini menunjukkan bahwa pemenuhan tepung ikan produksi dalam negeri belum mencukupi

Tepung ikan memiliki kisaran yang berbeda. Tepung ikan yang bermutu baik memiliki butiran - butiran seragam, bersih, bebas dari kontaminasi serangga, jamur, mikroorganisme pathogen, bebas dari sisa sisa tulang, mata ikan dan benda asing, seragam, serta bau khas ikan amis (Afrianto 42 dan Liviawaty, 2005). Makin baik mutu tepung ikan, makin tinggi harganya. Harga tepung ikan di pasaran sekitar Rp 5000 - Rp 9000 per $\mathrm{kg}$, tergantung kandungan proteinnya.. Harga tepung ikan, secara umum banyak ditentukan oleh presentase kandungan protein kasarnya. Tepung dengan rataan protein kasar yang tinggi akan semakin tinggi harganya. Tepung ikan impor berkualitas baik jika kandungan protein kasarnya bekisar antara $60-74 \%$ dengan kadar lemak bekisar antara 31,72 \% - 57,02 \%, lemak antara 4,57\%-20,68\%, dengan kadar air antara 7,33\%-11,16\% (Direktorat Jenderal Perikanan, 1998).

Cara pengolahan ikan menjadi tepung ikan melalui beberapa tahapan pada Gambar 2 yaitu :

1. Ikan direbus atau dikukus kurang lebih 30 menit atau sampai empuk dan agak hancur menjadi cake ikan

2. Lemak atau minyak dari ikan akan terpisah dan mengapung di permukaan air rebusan

3. Minyak ikan disaring untuk dipisahkan dari rebusan ikan. Minyak ikan ini dapat dijual untuk bahan suplemen minyak ikan

4. Cake ikan dijemur hingga kering

5. Cake ikan yang sudah kering digiling menjadi tepung ikan menggunakan mesin penepung

6. Tepung ikan diayak supaya hasilnya seragam, kemudian dikemas.

\section{Mesin penepung (disc mill)}

Mesin penepung ikan (disk mill) adalah mesin yang digunakan untuk menghancurkan ikan yang sudah dikeringkan, untuk dihaluskan menjadi tepung ikan. Proses penggiling ikan memanfaatkan energi mekanik yang dihasilkan dari putaran mesin untuk menggerakkan poros, dan putaran tersebut ditransmisikan dengan menggunakan sabuk-V (v-belt) kemudian putaran tersebut digunakan untuk menggerakkan cakram/disc penghancur sehingga ikan yang sudah kering 
menjadi butiran yang halus. Cakram penghancur merupakan komponen paling utama dari mesin penepung dengan tekanan dan gesekan antara dua piringan dimana bagian satu berputar dan yang lainnya tetap. Kedua piringan tersebut akan berputar secara bersamaan dengan arah berlawanan sehingga akan dapat menghancurkan bahan yang digiling. Pada bagian piringan ini terdapat tonjolan-tonjolan yang berfungsi untuk menjepit bahan. Selama proses, bahan akan mengalami gesekan diantara kedua piringan sehingga ukurannya menjadi lebih kecil dan halus.

Bagian-bagian dari disk mill (Stevie, dkk., 2011):

1. Corong Pemasukan: tempat masuknya bahan yang akan digiling.

2. Dinding penutup dan cakram: penghancur bahan karena adanya gerak putar dari cakram terhadap dinding penutup yang diam.

3. Corong pengeluaran: mempermudah dalam mewadahi bahan keluaran.

4. Ruang sirkulasi udara: mempermudah pemasukkan bahan dan pengeluran bahan dari cakram penggiling.

5. Poros penggerak: menggerakan atau memutar cakram pada disk mill, digerakkan oleh motor listrik dengan menggunakan puley dan belt sebagai penyalur daya.

\section{BAHAN DAN METODE}

Usaha yang komprehensif dilakukan untuk menyelesaikan masalah mitra. Strategi yang diambil dengan cara meningkatkan sumber daya manusia melalui penyuluhan dan praktek wirausaha, introduksi teknologi tepat guna, serta perbaikan managemen usaha. Sasarannya adalah dua kelompok masyarakat desa Puger Wetan. Tahapan kegiatan yang dilakukan dapat diuraikan sebagai berikut:
1. Penyuluhan tentang dampak limbah ikan, alih teknologi pemanfaatan limbah ikan menjadi tepung ikan dan prospeknya.

2. Alih teknologi tepat guna berupa alat penepung

3. Praktek Pembuatan tepung ikan dari ikan lemuru sisa

4. Penyuluhan managemen usaha, cara pemasaran dan pembuatan pembukuan sederhana

\section{HASIL DAN PEMBAHASAN}

Kegiatan Penyuluhan dampak limbah ikan, alih teknologi pemanfaatan limbah ikan menjadi tepung ikan dan prospeknya.

Kegiatan alih teknologi pemanfaatan limbah ikan lemuru menjadi tepung ikan ini berupa penyuluhan dan pelatihan. Mitra diajari cara membuat tepung ikan. Mitra juga diberi penjelasan tentang prospek dan peluang usaha produk tersebut yang masih terbuka luas karena sampai saat ini masih sangat sedikit pesaingnya.

Selama ini pengolahan limbah ikan menjadi tepung ikan identik dengan kebutuhan alat yang berukuran besar dan mahal. Akibatnya, pengusaha lebih banyak berperan dalam pengolahan ini daripada masyarakat. Minat masyarakat pada hal tersebut cenderung kurang karena terkait kendala penyediaan alat dan pendanaan. Karena itu, dipandang perlu untuk membuat suatu mesin berteknologi tepat guna penggiling limbah ikan menjadi tepung ikan yang tidak terlalu mahal. Mesin penggiling ikan adalah mesin yang digunakan untuk menghancurkan ikan yang telah kering, untuk dihaluskan menjadi tepung ikan. Selanjutnya tepung ikan dijadikan bahan dasar campuran makanan ternak, karena kandungan protein pada ikan sangat tinggi. 


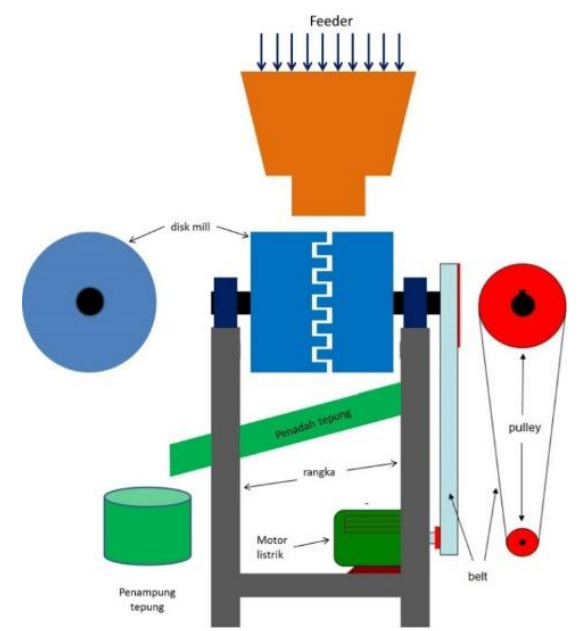

Gambar 1. Rancangan Alat Penepung

Alat yang dialihteknologikan dalam kegiatan ini berupa alat penepung (disc mill) dengan desain sebagaimana Gambar 1. Terdapat 2 ukuran alat dalam kegiatan ini, yaitu mesin dengan mesin 7 pk dan 20 pk. Mesin 20 pk ditujukan untuk skala produksi, saat limbah ikan dan sisa ikan melimpah, sehingga produksi lebih efektif dan efisien. Sedangkan alat penepung ukuran yang lebih kecil dimaksudkan untuk produksi tepung ikan pada saat jumlah bahan baku berupa ikan lemuru yang diolah untuk tepung ikan tidak terlalu banyak. Mesin kecil ini lebih dimaksudkan untuk pemanfaatan dan pengolahan limbah, sehingga dapat mengurangi dampak limbah terhadap lingkungan.

\section{Praktek Pembuatan tepung ikan dari ikan lemuru sisa dan pemasaran}

Produk yang dibuat dalam rangka menyelesaikan masalah mitra terkait masalah ekonomi dan lingkungan yaitu tepung ikan. Praktek cara membuat tepung ikan dimaksudkan agar mitra mengalami secara langsung bagaimana cara membuatnya, juga mengaplikasikan alat berteknologi tepat guna yang digunakan dalam proses produksi yaitu mesin penepung.

Produk berupa tepung ikan dikemas dalam kemasan sedang untuk penjualan pada peternak yang membuat sendiri pakan ternaknya. Selain itu, untuk mempermudah mitra memasarkan produknya, mitra telah dihubungkan dengan salah satu pengusaha local yang memproduksi tepung ikan dalam skala menengah dan telah memiliki pelanggan tetap dalam jumlah besar di sejumlah kota di Jawa Timur. Dengan demikian lebih menjamin proses pemasaran.

\section{Penyuluhan administrasi dan managemen serta cara pembuatan pembukuan sederhana}

Menurut Partomo \& Soedjoedono (2002), membuat pembukuan penting apabila sebuah bisnis ingin sustain/ bertahan lama. Pencatatan administrasi merupakan komponen yang harus diperhatikan dalam operasional usaha. Fungsinya untuk pencatatan, pengawasan dan dapat menjadi bahan analisa dan evaluasi untuk perkembangan usaha di masa mendatang. Pelaku usaha kecil biasanya adalah pemilik usaha yang memiliki fungsi ganda, karena itu manajer dalam usaha kecil berhadapan langsung dengan semua hal yang berkaitan dengan usaha, produksi, sumber daya, pemasaran, pengembangan usaha dan lainlain. Karena itu kemampuan manajemen mutlak diperlukan sebagai landasan kelangsungan usahanya.

Menurut Fajar (2013), pembukuan sederhana usaha diawali dari pencatatan arus kas. Karena dalam operasinya, keuangan usaha kecil dan rumahan umumnya masih terfokus pada transaksi tunai. Buku kas merupakan pos keuangan utama di mana seluruh uang terpusat. Isi dari buku kas mencatat seluruh pos penjualan dan pos belanja. Pos penjualan meliputi pencatatan seluruh penjualan produk yang dimiliki. Pos belanja mencatat semua hal yang berhubungan dengan pengeluaran usaha. Baik itu untuk belanja bahan baku, operasional, maupun gaji karyawan. 
Awal pencatatan dimulai dari saldo yang berasal dari modal yang disetor oleh pemilik usaha ataupun yang berasal dari saldo bulan sebelumnya (dicatat sebagai uang masuk). Saldo tersebut oleh pemilik usaha kemudian dikelola untuk belanja bahan produksi untuk menghasilan produk. Hasil penjualan produk kemudian dicatat dan uangnya. Setelah periode tertentu, dapat dilihat posisi saldo usaha. Yaitu selisih antara uang masuk dan uang yang dikeluarkan untuk pos belanja.

Pembukuan untuk usaha kecil dan rumahan tidak perlu rumit ataupun mahal. Dengan modal yang relatif murah, pemilk usaha bisa memiliki pembukuan sederhana untuk mencatat transaksi keuangannya. Ini merupakan sebuah langkah menuju sistem pembukuan yang lebih baik dan kelak dapat memudahkan pemilik usaha dalam menerapkan sistem akuntansi yang lebih lengkap.

\section{Evaluasi}

Evaluasi kegiatan ini dilakukan dalam masa pelaksanaan kegiatan dengan meninjau langsung bagaimana mitra dalam melaksanakan semua yang disampaikan dan dipraktekkan serta memantau perubahan yang terjadi pada kelompok sasaran, baik pada aspek usaha/produksi, managemen maupun kebersihan lingkungan. Berdasarkan pengamatan dan wawancara, beberapa hal penting yang dapat dicapai dalam kegiatan ini.

\section{Manfaat dari aspek ekonomi}

Dari sisi ekonomi, kegiatan ini dapat menambah penghasilan mitra. Hal ini antara lain karena mitra tetap bisa mendapatkan penghasilan meskipun tidak sedang melaut melalui pembuatan tepung ikan. Bahan baku Tepung ikan didapatkan dari hasil tangkapan sendiri beberapa hari sebelumnya dan telah dikeringkan, atau membeli ikan rucah kering dari nelayan lain atau pedagang ikan. Secara tidak langsung akan meningkatkan pendapatan nelayan lain (selain mitra) karena hasil tangkapannya yang tidak terserap pasar tetap bisa bernilai ekonomi karena dibeli oleh mitra untuk bahan baku pembuatan tepung ikan.

Mitra diharapkan dapat mengembangkan usahanya. Jika skala usaha berkembang dengan baik, akan dapat menyerap tenaga kerja lebih banyak dan mengurangi pengangguran. Berkembangnya usaha tidak hanya dibutuhkan pengetahuan saja tapi kemampuan berwirusaha yang mumpuni, dengan menguasai seluk beluk tentang kewirausahaan. Kemampuan ini dapat berupa bakat maupun hasil latihan atau praktik. Menurut Suryana (2006), Kemampuan yang harus dimiliki seorang wirausaha diantaranya: kemampuan memperhitungkan risiko, kemampuan berpikir kreatif, kemampuan managemen, kemampuan berkomunikasi dan berinteraksi serta menguasai strategi keuangan dan pemasaran. Dengan demikian, pelatihan yang diberikan dalam kegiatan ini menumbuhkan jiwa kewirausahaan yang merangsang munculnya ide-ide wirausaha lain, sehingga diharapkan usahanya makin berkembang dan terjadi diversifikasi usaha.

Jika ditinjau dari jenis mesin yang dialihteknologikan, yaitu mesin pembuat tepung, mesin tesrsebut dapat dimanfaatkan untuk menepungkan bahana lain asalkan kering, seperti kopi, jagung, bersa, kedelai, dan lain-lain. Dengan demikian, pada masamasa paceklik ikan, mesin penepung masih dapat dimanfaatkan bahkan dpat digunakan untuk berproduksi jenis produk non ikan. Sehingga kemanfaatana dan efektifitas mesin tersebut tinggi, tergantung dari kreatifitas dari mitra dalam pengembangan dan diversifikasi jenis usahanya 


\section{Manfaat dari aspek lingkungan hidup}

Melalui kegiatan ini, dapat mengurangi limbah yang diakibatkan oleh limbah padat ikan, sehingga lingkungan menjadi lebih sehat dan indah. Ikan sisa maupun ikan rucah yang semula tidak diolah, dibiarkan dan mencemari lingkungan, saat ini dimanfaatkan dengan baik dengan diolah menjadi produk yang bermanfaat yaitu tepung ikan. Dengan demikian dapat mengurangi penyebab penyakit, yaitu gatal-gatal, diare, thypus.

Secara umum, mitra sangat bersemangat terhadap kegiatan ini. Bahkan mereka memiliki ide untuk menggunakan alat yang telah dihibahkan kepada mereka untuk hal lain yang bermanfaat terutama saat bahan baku tepung ikan kurang, antara lain menggiling beras, jagung atau kopi menjadi bentuk bubuk halus. Selain itu, mitra juga berminat untuk mengolah hasil samping dari pengolahan tepung ikan yaitu minyak ikan. Minyak ikan ini jika diolah dengan benar akan mengandung nutrisi yang sangat tinggi, dan memiliki nilai jual yang tinggi. Dengan demikian, akan menambah pendapatan mitra dan meningkatkan kesejahteraan mitra.

Secara keseluruhan, dari berbagai kegiatan dan solusi yang ditawarkan akan dapat menyelesaikan masalah yang dihadapi kedua mitra sebelum adanya program IbM sebagaimana pada Tabel .

Tabel 1. Perbandingan Sebelum dan Sesudah Program $I_{b} M$

\begin{tabular}{|l|l|}
\hline \multicolumn{1}{|c|}{ SEBELUM ADA PROGRAM $\mathrm{I}_{\mathrm{b}} \mathrm{M}$} & \multicolumn{1}{|c|}{ SETELAH ADA PROGRAM $\mathrm{I}_{\mathrm{b}} \mathrm{M}$} \\
\hline $\begin{array}{l}\text { Lingkungan kotor oleh ikan sisa yang dibuang dan } \\
\text { jadi limbah }\end{array}$ & Pencemaran lingkungan oleh ikan sisa berkurang \\
\hline $\begin{array}{l}\text { Ikan sisa, baik ikan rucah maupun ikan segar yang } \\
\text { tidak terserap pasar hanya dibuang, tidak } \\
\text { dimanfaatkan }\end{array}$ & $\begin{array}{l}\text { Ikan sisa memiliki nilai tambah dengan diolah } \\
\text { menjadi tepung ikan }\end{array}$ \\
\hline $\begin{array}{l}\text { Saat tidak musim lemuru, hasil tangkapan sedikit } \\
\text { sehingga pendapatan rendah bahkan tidak } \\
\text { memperoleh pendapatan }\end{array}$ & $\begin{array}{l}\text { Saat tidak musim lemuru, mitra tetap bisa } \\
\text { mendapat penghasilan dengan membuat tepung } \\
\text { ikan dari ikan jenis lain }\end{array}$ \\
\hline $\begin{array}{l}\text { Tidak ada tambahan pendapatan saat musim ikan } \\
\text { karena kelebihan ikan tidak terserap pasar (tidak } \\
\text { laku dijual) }\end{array}$ & $\begin{array}{l}\text { Keuntungan bertambah terutama saat musim ikan } \\
\text { karena semua ikan dapat dimanfaatkan dan } \\
\text { bernilai ekonomi }\end{array}$ \\
\hline Pekerjaan hanya di laut sebagai nelayan & \begin{tabular}{l} 
Memiliki pekerjaan sampingan di darat \\
\hline Tidak memiliki ide wirausaha \\
dengan pengolahan minyak ikan, silase ikan, dll.
\end{tabular} \\
\hline Tidak memahami managemen usaha & $\begin{array}{l}\text { Memahami managemen usaha secara sederhana } \\
\text { dan pembukuan sederhana }\end{array}$ \\
\hline
\end{tabular}

\section{KESIMPULAN}

Kegiatan pengembangan pengolahan tepung ikan melalui alih teknologi dan bantuan alat serta pelatihan dan praktek produksi bermanfaat bagi mitra maupun masyarakat sekitar mitra baik secara ekonomi maupun lingkungan. Secara ekonomi, dapat meningkatkan penghasilan mitra melalui 46 pengolahan ikan sisa menjadi produk tepung ikan yang bermanfaat dan prospek usahanya masih cerah, juga bagi masyarakat sekitar yang hasil tangkapannya tidak terserap pasar, tetap memiliki nilai ekonomis dengan dijual pada produsen tepung ikan. Manfaat bagi lingkungan adalah mencegah pemborosan sumberdaya alam dan mengurangi 
pencemaran lingkungan karena tidak ada lagi ikan sisa yang terbuang percuma, namun dapat diolah menjadi tepung ikan.

\section{UCAPAN TERIMA KASIH}

Kemenristek Dikti melalui program IbM 2015

\section{DAFTAR PUSTAKA}

Afrianto, E dan and Liviawaty,E. 2005. Tepung Ikan dan Pengembangannya Kanisius, Yogyakarta.

Akhiarif. 2011. Cara pembuatan tepung ikan. http://id.shvoong.com/writing-andspeaking/2124819-cara-pembuatantepung-ikan/\#ixzz2zlZUdRpC [24 April 2014].

Alfiyah, Y. 2012. Tepung Ikan Tradisional Campuran Pakan Alternatif Unggas, Sapi, dan Domba Ikan. http://www.scribd.com/doc/93039017/1 4349074-TEPUNG-IKAN [25 April 2014].

Amri, K. 2007. Ikan Lemuru Berbaju Sarden. Majalah Intisari, Januari 2007

Fajar, A. 2013. Pembukuan Sederhana Usaha Kecil dan Rumahan. http://adityafajar.com/pembukuansederhana-usaha-kecil-dan-rumahan [21 April 2014].

Kementerian Kelautan Perikanan. 2012. Buku Statistik Ekspor dan Impor Hasil Perikanan Indonesia Tahun 2011. statistik.kkp.go.id/index.php/arsip/file/5 1/buku_impor.pdf, [22 april 2014]

Merta, I.G.S. 1992. Dinamika Populasi Ikan Lemuru (Sardinella lemuru) di Perairan Selat Bali dan Alternatif Pengelolaannya. Disertasi. Bogor: Program Sekolah Pasca Sarjana. Institut Pertanian Bogor.

Murtidjo, B.A. 2003. Beberapa Metode Pengolahan Tepung Ikan. Kanisius. Yogyakarta
Nurhayat, W. 2015. Impor Tepung Ikan Capai $\begin{array}{lll}\mathrm{Rp} & 5,7 & \text { Triliun/Tahun. }\end{array}$ http://finance.detik.com/read/2015/01/0 5/185900/2794634/4/impor-tepungikan-capai-rp-57-triliun-taun. [05/01/2015]

Partomo, TS., Soejoedono, AR. 2002. Ekonomi Skala Kecil/Menengah \& Koperasi. Ghalina Indonesia, Jakarta.

Prabowo, D. 2004. Suplementasi Minyak Ikan Lemuru pada Ransum Dasar terhadap Kadar Kolesterol Telur, Titer Kekebalan ND dan Produksi Telur Ayam Petelur. Tesis. Program Pascasarjana Unsoed. Purwokerto.

Redjeki, S., Trinovani, E. 2012. Pengaruh Penambahan Tepung Ikan Lemuru terhadap Kandungan Omega-3 pada Telur Ayam. http://lppm-poltekkesbdg.blogspot.com/2012/01/pengaruhpenambahan-tepung-ikan-lemuru.html [22 April 2014]

Stevie, I., Wardhani, R., Jatmiko, P.B. 2011. Rancang Bangun Mesin Penggiling Limbah Ikan Menjadi Tepung Ikan Dengan Kapasitas 118,8 Kg/Jam. http://digilib.its.ac.id/public/ITS-paper25040-2109039027-Paper1, pdf [20 April 2014].

Sukirno, Sriharti. 2000. Analisis Penerapan IPTEKDA Pada Unit Usaha Tepung Ikan Jumina Di Desa Kesenden Kecamatan Kejaksan Cirebon. Prosiding. Seminar Peran teknologi Tepat Guna Terhadap Pengembangan IPTEKS dan SDM Dalam rangka Menyongsong Otonomi Daerah. Nopember 2000.

Suryana. 2012. Kewirausahaan. Salemba Empat, Jakarta. 